\title{
Isolation and characterization of mannanase, xylanase, and cellulase from marine bacteria Bacillus sp.
}

\author{
YOPI", APRIDAH CAMELIAWATI DJOHAN, NANIK RAHMANI, ALIFAH MAFATIKHUL JANNAH \\ Research Center for Biotechnology, Indonesian Institute of Sciences. Jl. Raya Jakarta-Bogor Km. 46, Cibinong, Bogor 16911, West Java, Indonesia. \\ •email: yopi_sunarya@gmail.com.
}

Manuscript received: 21 March 2016. Revision accepted: 28 January 2017.

\begin{abstract}
Yopi, Djohan AC, Rahmani N, Jannah AM. 2017. Isolation and characterization of mannanase, xylanase, and cellulase from marine bacteria Bacillus sp. Biofarmasi J Nat Prod Biochem 15: 15-20. Isolation, identification, and characterization of mannanase, xylanase, and cellulase-producing indigenous marine bacteria have been conducted from a total of 20 isolates. Based on 16S rDNA sequence analysis, three potential isolates are obtained and identified Bacillus subtilis (M8), Bacillus tequilensis (X4), and Bacillus cereus (C9). The potential strains M8, X4 and C9 can produce mannanase, xylanase and cellulase activities such as 9.5 U/mL; $0.36 \mathrm{U} / \mathrm{mL} ; 0.56 \mathrm{U} / \mathrm{mL}$ with optimum $\mathrm{pH}$ and temperature $6.0 ; 50^{\circ} \mathrm{C}, 5.5 ; 70^{\circ} \mathrm{C}$ and $8 ; 50^{\circ} \mathrm{C}$, respectively. Based on the TLC analysis, mannanase from M8 and xylanase from X4 has the potential to hydrolyze mannan and xylan for producing oligosaccharides with the size around tri-hexasaccharide as the main product.
\end{abstract}

Keywords: Bacillus sp., cellulase, hemicellulase, marine bacteria, oligosaccharide.

\section{INTRODUCTION}

The utilization of cellulose by microorganisms involves a substantial set of fundamental phenomena beyond those associated with enzymatic hydrolysis of cellulose (Lynd et al. 2002). Marine biodiversity microorganism has high potency for biotechnology and the enzymatic environment in Indonesia. There is a deep interest in searching for new enzymes source of cellulase and hemicellulase for industrial application (Sukumaran et al. 2005).

Marine microorganisms have been regarded as a reservoir, not only for novel natural products but also for valuable genes and enzymes (Guo et al. 2013). Several xylanases produced by marine microorganisms from special habitats, such as the deep-sea hydrothermal field (Wu et al. 2006), the Antarctic marine soil (Collins et al. 2002), and marine sediment (Guo et al. 2009), were shown to have special properties, such as hyperthermostability (Wu et al. 2006), cold adaptation (Collins et al. 2002; Guo et al. 2009) and salt-tolerance (Guo et al. 2009; Liu et al. 2012).

The utilization of marine bacteria to produce cellulase and hemicellulase has not been used widely in Indonesia. There is a report related to isolated marine bacteria from Pari island, which have the ability to produce mannanase (Djohan 2014). We have already collected marine microbes from Bali Island and already identified them using $16 \mathrm{~S}$ rRNA as cellulase and hemicellulase marine microbe belonging to Bacillus sp.

This research intends to isolate and characterize cellulose and hemicellulose deriving from marine microbes for new enzyme applications in biotechnology fields, especially to convert abundant cellulose and hemicellulose biomass into monosaccharides that can be converted into bioethanol through fermentation yeast.

\section{MATERIALS AND METHODS}

Isolation mannanase, xylanase, and cellulase producing marine bacteria

Mannanase, xylanase, and cellulase-producing bacteria were isolated from seawaters and sediment collected on Bali Island. The Locust Bean Gum (LBG), CMC, and Xylan are mediums for screening and purifying bacteria and contain $0.5 \%$ of substrate (LBG, CMC, and Xylan), $0.075 \%$ of peptone, $0.05 \%$ of extracted yeast which were then diluted in Artificial Sea Water (ASW) at pH 6.0 (Mandels and Sternberg 1976). The purified colonies were preserved at $4^{\circ} \mathrm{C}$ for further study.

\section{Screening of mannanase, xylanase, and cellulase producing marine bacteria}

Pure cultures of bacteria isolates were transferred individually in CMC, xylan, and LBG agar plates. After incubation for one day, these agar plates were flooded with $0.2 \%$ red congo and allowed to stand for $30 \mathrm{~min}$ at room temperature for counterstaining the plates, $\mathrm{NaCl} 1 \mathrm{M}$ solution was thoroughly used. The bacteria colonies with the largest clear zone were selected to identify and produce cellulase, xylanase, and mannanase in submerged fermentation.

\section{Identification and phylogenetic analysis 16S rDNA sequence}

The 16S rRNA gene was amplified by polymerase chain reaction (PCR) technique using a pair of primer 9F: 5'-AGRGTTTGATCMTGGCTCAG-3' and 1492R: 
5'TACGGYTACCTTGTTAYGACTT-3' (Burggraft et al. 1992). The obtained bands were stained in Bio and were visualized by a UV transilluminator.

\section{Production of mannanase, xylanase, and cellulase}

For fermentation, Mannanase, xylanase, and cellulase were produced by three potential isolates $(\mathrm{M} 8, \mathrm{X} 4$, and C9), precultured in a $100 \mathrm{~mL}$ flask containing $10 \mathrm{~mL}$ of ASW cultivated at $30^{\circ} \mathrm{C}$ for one day. The preculture medium was seeded into a $300 \mathrm{~mL}$ flask containing $30 \mathrm{~mL}$ of ASW medium with adjusted cell 0.02 (OD $\lambda=660)$ and incubated at $30^{\circ} \mathrm{C}$ for six days.

\section{Mannanase, xylanase, and cellulase activity assay}

Mannanase, xylanase, and cellulase activity were assayed by measuring the reducing sugars using the dinitro salicylic acid (DNS) method (Miller 1959). Cellulase activity was measured using substrate $0.5 \%$ of CMC (Sigma) and dissolved in $50 \mathrm{mM}$ sodium phosphate buffer, $\mathrm{pH} 7.0$. An appropriately diluted enzyme solution $(250 \mu \mathrm{L})$ was incubated with $250 \mu \mathrm{L}$ of the substrate solution at $60^{\circ} \mathrm{C}$ for $15 \mathrm{~min}$. The amount of reducing sugars released in the enzyme reaction was assayed by mixing $750 \mu \mathrm{L}$ of DNS solution, heating it at $100^{\circ} \mathrm{C}$ for $10 \mathrm{~min}$, then cooling it on ice for $10 \mathrm{~min}$, and measuring the absorbance at 540 $\mathrm{nm}$. One unit of cellulase activity is defined as the amount of enzyme that releases $1 \mu \mathrm{mol}$ of $\mathrm{D}$-glucose per minute under the experimental condition given.

Xylanase activity was measured using $250 \mu \mathrm{L}$ of the substrate solution of $0.5 \%$ xylan (Sigma). An appropriately diluted enzyme solution $(250 \mu \mathrm{L})$ dissolved in $50 \mathrm{mM}$ sodium phosphate buffer with $\mathrm{pH} 7.0$ was incubated at $60^{\circ} \mathrm{C}$ for $15 \mathrm{~min}$. After incubation, $750 \mu \mathrm{L}$ DNS solution was added to end the reaction. The amount of reducing sugars released in the mixture was determined, with xylose as the standard using the DNS method (Miller 1959). One unit of xylanase activity is defined as the amount of enzyme capability to release $1 \mu \mathrm{mol}$ of xylose per minute under the assay condition.

Mannanase activity was measured using a substrate of $0.5 \%$ LBG (sigma) which was dissolved in $50 \mathrm{mM}$ of sodium phosphate buffer, $\mathrm{pH}$ 7.0. An appropriately diluted enzyme solution $(250 \mu \mathrm{L})$ was incubated with $250 \mu \mathrm{L}$ of the substrate solution at $60^{\circ} \mathrm{C}$ for $15 \mathrm{~min}$. The amount of reducing sugars released in the enzyme reaction was assayed by mixing $750 \mu \mathrm{L}$ of DNS solution, heating it at $100^{\circ} \mathrm{C}$ for $10 \mathrm{~min}$, cooling it on ice for $10 \mathrm{~min}$, and measuring the absorbance at $540 \mathrm{~nm}$. One unit of mannanase activity is defined as the amount of enzyme that liberates $1 \mu \mathrm{mol}$ of D-mannose per minute under the experimental condition given.

\section{Characterization of optimum $\mathrm{pH}$ and temperature}

The optimum enzyme activity $\mathrm{pH}$ was examined at $\mathrm{pH}$ 3.0-10.0 under standard assay conditions. Fifty $\mathrm{mM}$ of various buffers were used: sodium citrate $(\mathrm{pH} 3.0-5.0)$, sodium phosphate $(\mathrm{pH}$ 6.0-8.0), and glycine $\mathrm{NaOH}(\mathrm{pH}$ 9.0-10.0). The enzyme reaction was incubated at $50^{\circ} \mathrm{C}$ for $15 \mathrm{~min}$ in the presences of $0.5 \%$ (w/v) LBG for mannanase, $0.5 \%(\mathrm{w} / \mathrm{v})$ xylan for xylanase and $0.5 \%(\mathrm{w} / \mathrm{v}) \mathrm{CMC}$ for cellulose. The effect of temperature on enzyme activity was performed at a temperature ranging from $30-90^{\circ} \mathrm{C}$ in 50 $\mathrm{mM}$ acetate buffer at optimum $\mathrm{pH}$ for $15 \mathrm{~min}$.

Cellulosa and hemicellulose hydrolysis analysis by using thin-layer chromatography

Hydrolysis on mannan substrates (LBG, Konjac glucomannan, Ivory nut, porang), xylan (xylan), and cellulose (CMC) was carried out at $50^{\circ} \mathrm{C}$ in $50 \mathrm{mM}$ of sodium phosphate buffer, $\mathrm{pH} 6$, containing $0.5 \%$ for each substrate. The enzyme-substrate ratio $(\mathrm{v} / \mathrm{v})$ was $1: 1$ and the reaction time was from $0,0.5,1,2,4,8,12$ and 24 hours. The reaction was carried out in $1.5 \mathrm{~mL}$ of Eppendorf containing $100 \mu \mathrm{L}$ of reaction mixtures in the dry block. Thin Layer chromatography (TLC) of oligosaccharides was carried out on silica gel $60 \mathrm{~F}_{254}$ plates (Merck Art 20x20 $\mathrm{cm}$ ) and eluent with a solvent mixture of n-Butanol/Acetic acid/Water (12: 6: 6, v/v/v). The spots were visualized by TLC dye reagent, i.e., DAP $(0.5 \mathrm{~g} \alpha$-diphenylamine, $25 \mathrm{~mL}$ acetone, $2.5 \mathrm{~mL}$ phosphate acid, $0.5 \mathrm{ml}$ aniline) and subsequently heated at $120^{\circ} \mathrm{C}$ for $15 \mathrm{~min}$. The samples were applied in equal quantities $(4 \mu \mathrm{L})$. Glucose, mannose (Sigma-Aldrich, U.S.A.), mannobiose (M2), mannotriose (M3), mannotetraose (M4), and mannopentaose (M5) and mannohexaose (all from Megazyme, Ireland) were used as a standard.

\section{RESULTS AND DISCUSSION}

\section{Isolation of cellulose and hemicellulose from marine bacteria}

The research collected 20 isolates from a screening medium of artificial seawater and bacteria that could produce several types of enzymes, such as mannanase, xylanase, and cellulase enzyme. Then they were screened further for their abilities to excrete enzymes in some substrates, such as the locust bean galactomannan substrate, which is a medium for getting the mannanase, xylene for getting the xylanase, and CMC for getting the cellulase potential marine microbe. Isolation on cellulose and hemicellulose of marine bacteria using some substrate (locust bean gum, xylan, CMC) has been done using congo red analysis (Figure 1). For the mannolytic microbe, we obtain 11 isolates that produce mannanase. Still, only the M8 isolate produces the highest mannanase activity; for xylanase, we obtain one isolate $\mathrm{X} 4$, and for cellulase, we obtain one isolate $\mathrm{C} 9$.

\section{Identification of the purified isolates based on the $16 \mathrm{~S}$ rDNA sequence}

Based on the sequence analysis of the 16S rDNA gene against the GenBank database, there is an indication that 3 selected isolates were closely related to the members of the genus Bacillus. The phylogenetic analysis showed about 99\% similarity between isolate M8 and Bacillus subtilis, isolate $\mathrm{X} 4$ and Bacillus tequilensis, and isolate $\mathrm{C} 9$ and Bacillus cereus (Table 1). 


\section{Production of mannanase, xylanase, and cellulase}

The crude enzyme production was done from marine bacteria (M8 isolates for mannanase, $\mathrm{X} 4$ for xylanase, and C9 for cellulase) for 144 hours of culture (Figure 2), which were grown in ASW medium with shaking (180 rpm) at $30^{\circ} \mathrm{C}$.

The members of the genus Bacillus produce large varieties of extracellular cellulase and hemicellulase, such as cellulase, mannanase, and xylanase, which are significantly important enzymes for industrial demand. These quantitative enzyme tests have been conducted to determine the ability of each isolate to produce an enzyme using commercial substrates as a carbon source. The isolates produce enzymes using commercials substrate as a carbon source with maximal activity at 72 hours of culture, such as xylanase $0.36 \mathrm{U} / \mathrm{mL}$, mannanase $9.5 \mathrm{U} / \mathrm{mL}$, and cellulase $0.56 \mathrm{U} / \mathrm{mL}$.

\section{Characterization of optimum $\mathrm{pH}$ and temperature}

The effect of $\mathrm{pH}$ on the activity of Mannanase M8, xylanase $\mathrm{X} 4$, and cellulase $\mathrm{C} 9$ was carried out in the range 3-10, as shown in Figure 3. The crude mannanase M8 was active at a wide $\mathrm{pH}$ range from 5.0-10.0, xylanase $\mathrm{X} 4$ from 3.0 to 10.0 , and cellulase C9 from 3.0-9.0. The highest mannanase, xylanase, and cellulase activity were observed at pH 6.0, 5.5, and 8.0, respectively (Figure 3.A, 3.C, 3.E).
The increase or decrease of $\mathrm{pH}$ depends on enzyme activity. The effect of temperature was studied on each enzyme activity by varying the value from $30^{\circ} \mathrm{C}$ to $100^{\circ} \mathrm{C}$. The effects of temperature on the activity of Mannanase M8 were shown in Figure 5.B with the optimum temperature at $70^{\circ} \mathrm{C}$ and high enzyme activity of $9.5 \mathrm{U} / \mathrm{mL}$. The report of xylanase X4 was shown in Figure 5.D, in which the optimum temperature is $70^{\circ} \mathrm{C}$, with the activity of $2.2 \mathrm{U} / \mathrm{mL}$. The report of cellulase $\mathrm{C} 9$ is shown in Figure $5 . \mathrm{F}$, which optimum temperature is $50^{\circ} \mathrm{C}$ with an activity of $0.26 \mathrm{U} / \mathrm{mL}$. The enzyme activity increased when the temperature increased from $40^{\circ} \mathrm{C}$, but the activity started to decline as the temperature increased above $80^{\circ} \mathrm{C}$ and became completely denatured at $100^{\circ} \mathrm{C}$. Similar findings were also reported by some species, i.e., Bacillus sp and B.subtilis YJ1, which have an optimum temperature of $50^{\circ} \mathrm{C}$ (Kim et al. 2011).

Table 1. The phylogenetic analysis showed about $99 \%$ similarity between the isolated M8 and Bacillus subtilis, isolate $\mathrm{X} 4$ and Bacillus tequilensis, and isolate C9 and Bacillus cereus

\begin{tabular}{lll}
\hline Code of strain & Isolated from & Identified as* \\
\hline M8 & Sea water & Bacillus subtilis \\
X4 & Sea water & Bacillus tequilensis \\
C9 & Sea water & Bacillus cereus \\
\hline
\end{tabular}

Note: *by 16S rRNA gene sequencing

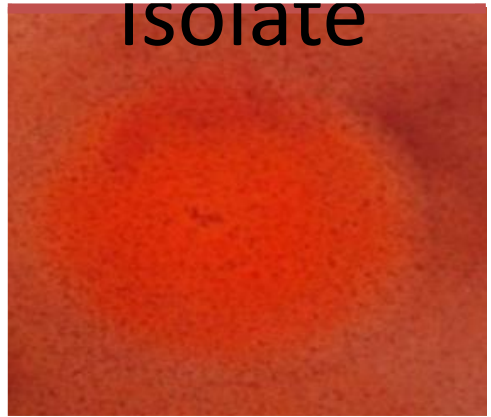

A

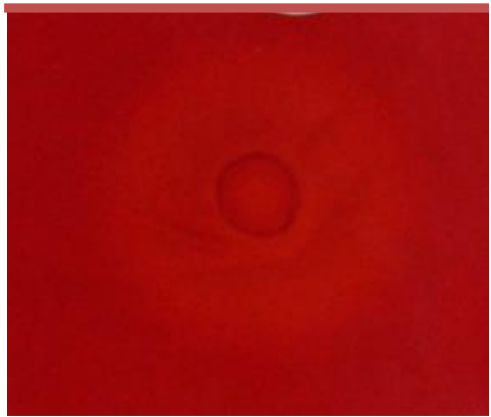

B

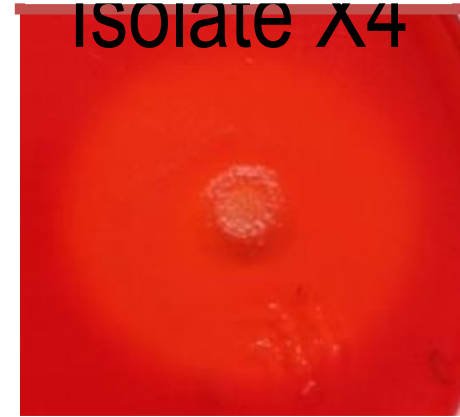

$\mathbf{C}$

Figure 1. Congo red analysis from (A) mannolytic M8, (B) cellulolytic C9, and (C) xylanolytic X4 in a medium that uses a specific substrate (LBG, xylan, and CMC) for 24 hours of incubation

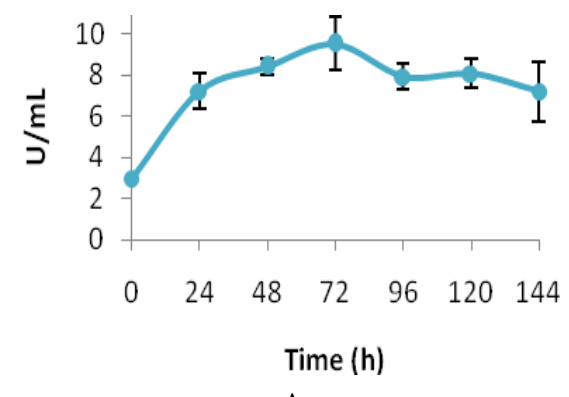

A

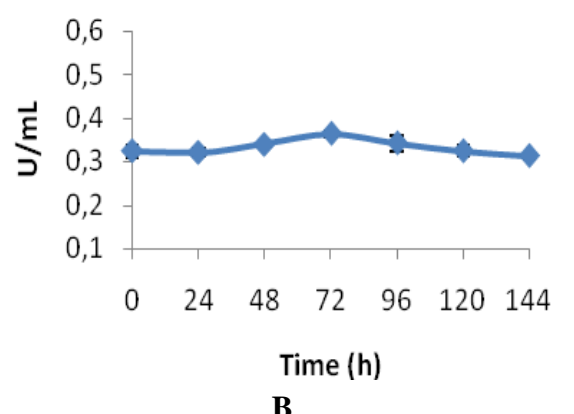

B

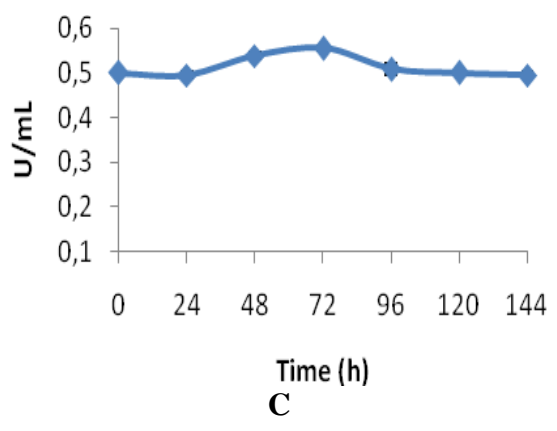

C

Figure 2. Crude enzyme production from potential marine bacteria with 24 hours retention times for initial optimation, such as mannanase M8 (A), xylanase X4 (B), and cellulase C9 (C). 


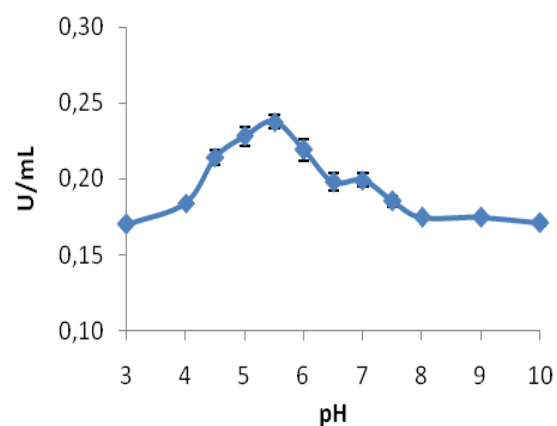

A

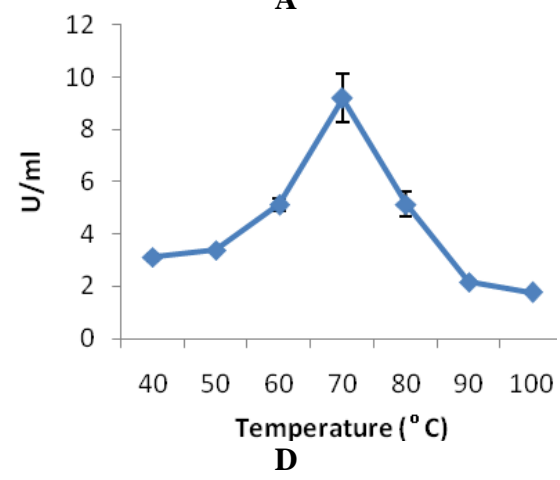

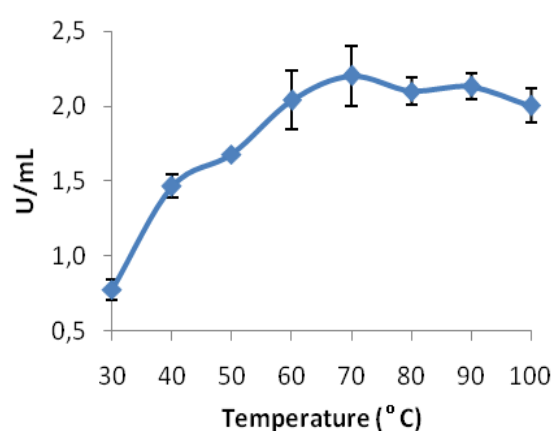

B

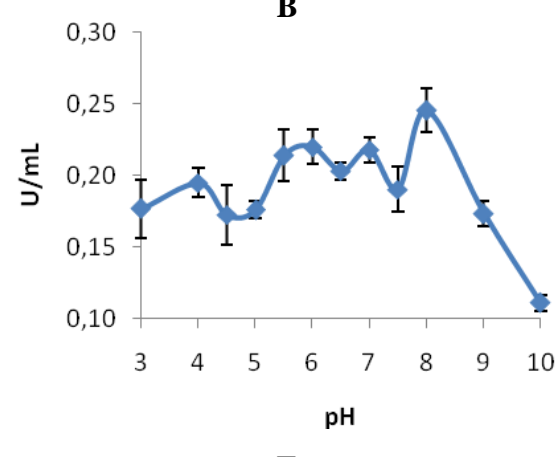

$\mathbf{E}$

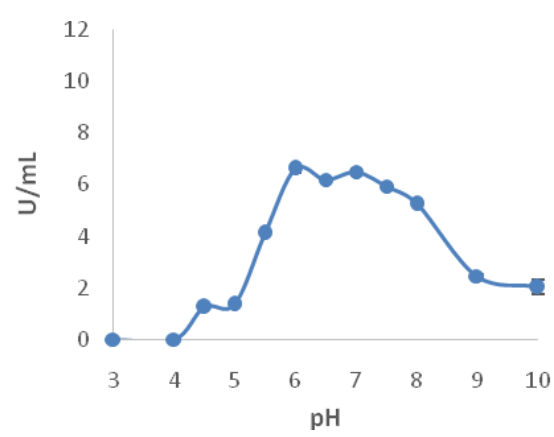

C

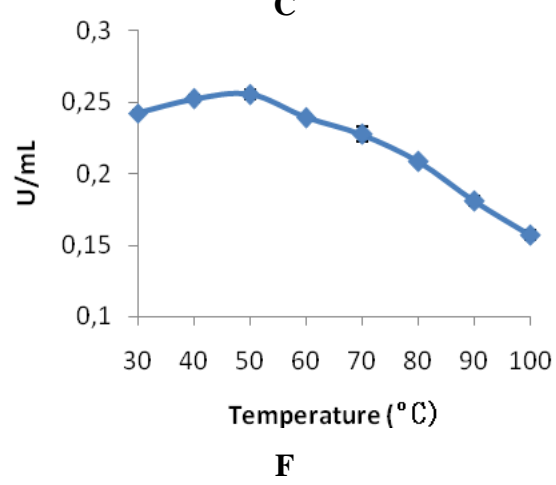

Figure 3. Characterization of $\mathrm{pH}$ and temperature xylanase from isolate $\mathrm{X} 4$ (A, B), mannanase from isolate M8 (C, D), and cellulase from isolate C9 $(\mathrm{E}, \mathrm{F})$
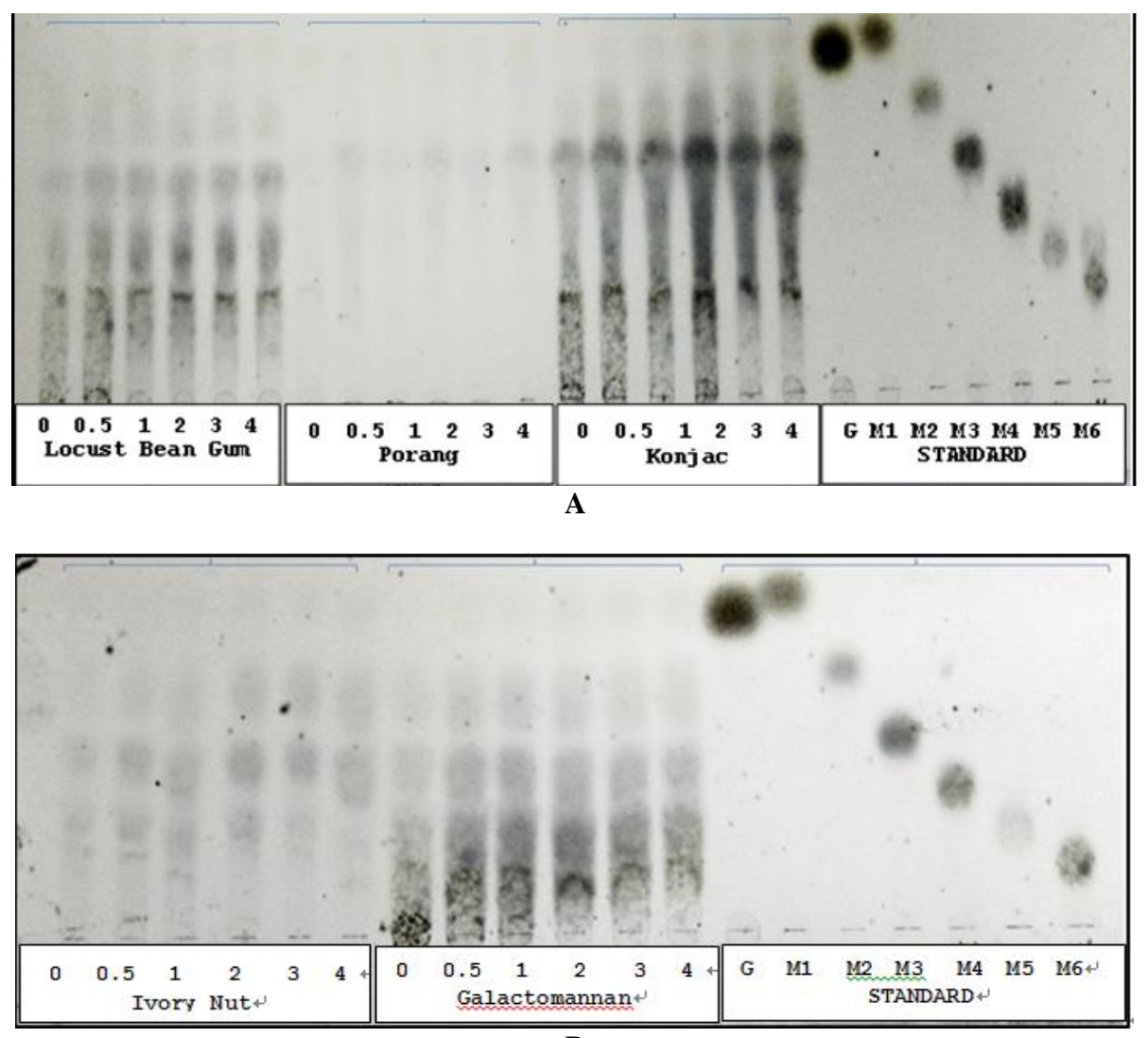

B

Figure 4. Thin-layer chromatography analysis of hydrolysis products mannanase M8 using various mannan as substrates, namely, LBG, porang, konjac glucomannan (A) and galactomannan, and ivory nut (B). Standards (STD): glucose (G), mannobiose (M2), mannotriose (M3), mannotetraose (M4), mannopentaose (M5), and mannohexaose (M6). Substrate: enzyme (v/v) = 1: 10 and 1: 5, Substrate concentration $0.5 \%$ in $50 \mathrm{mM}$ sodium phosphate buffer ( $\mathrm{pH} 6.0$ ), reaction time (hours): $0,0.5,1,2,3$ and 4 at $30^{\circ} \mathrm{C}$ condition. 


\section{Product analysis by thin-layer chromatography}

The hydrolysis of mannan sources such as locust bean gum, porang, konjac, ivory nut, and galactomannan by marine bacteria M8 was shown in Figures 4.A and 4.B. The product was analyzed using the TLC method and resulted in several types of oligosaccharides, such as mannose, mannobiose, mannotriose, and mannotetraose, as the main product.

The oligosaccharide production from porang substrate showed the thin spot result because porang was a raw material that was more difficult to hydrolyze than a commercial substrate that was already pure. The experiment showed that the hydrolysis process by M8 continuously produced various oligosaccharide products in different reaction times and continued to increase until it completely degraded in short times.

The hydrolysis of cellulose sources such as bagasse, porang, and konjac glucomannan by Cellulase C9 is shown in Figure 5. The product was analyzed using the TLC method and resulted in a thin chromatogram or almost spotless. It is because baggase and porang were still raw materials. On konjac glucomannan, it resulted from thin spots of cellulose compound.

The hydrolysis of xylan sources such as xylan birchwood, EFB, and baggase by xylanase X4 is shown in Figure 6 . The products were identified as xylotetraose, xylopetaose, and xylohexaose, which were the main products of the hydrolysis process.

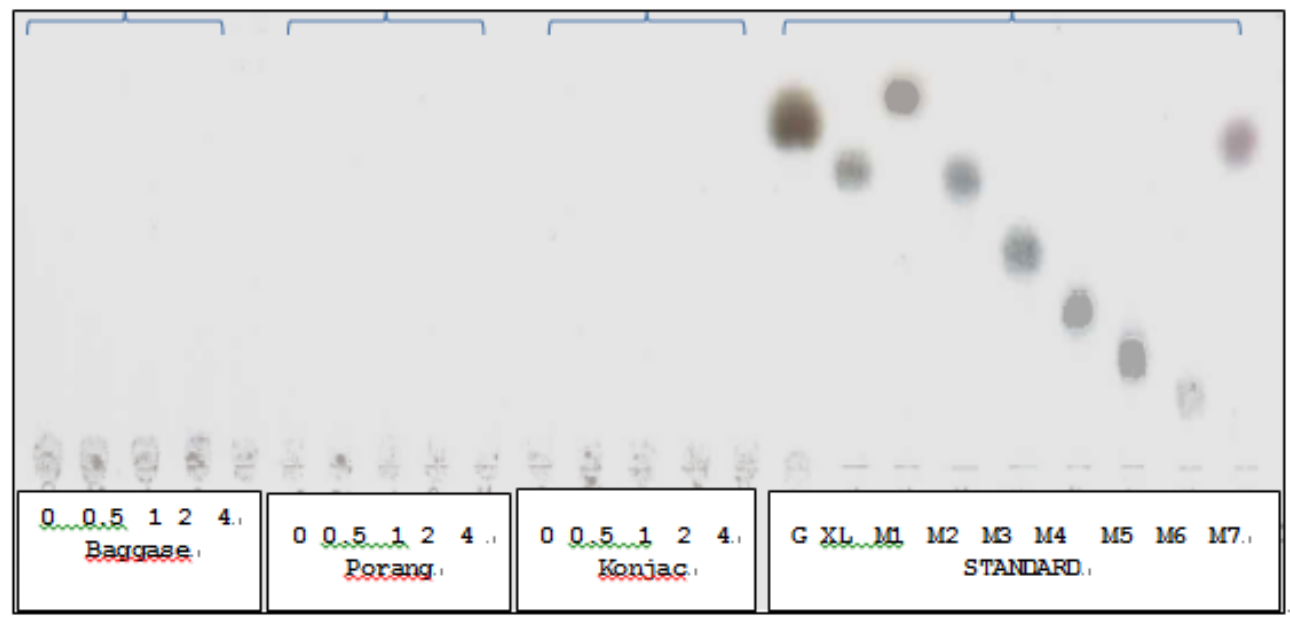

Figure 5. Thin layer chromatography analysis of hydrolysis products of cellulase C9 using Carboxymetylcellulose, Baggase, EFB as a substrates. Standards (STD): glucose (G), xylose (M2), mannotriose (M3), mannotetraose (M4), mannopentaose (M5) and mannohexaose (M6). Substrate: enzyme $(\mathrm{v} / \mathrm{v})=1: 10$ and 1: 5, Substrate concentration $0.5 \%$ in $50 \mathrm{mM}$ sodium phosphate buffer (pH $6.0)$, reaction time (h): $0,0.5,1,2,3$ and 4 at $30^{\circ} \mathrm{C}$ condition

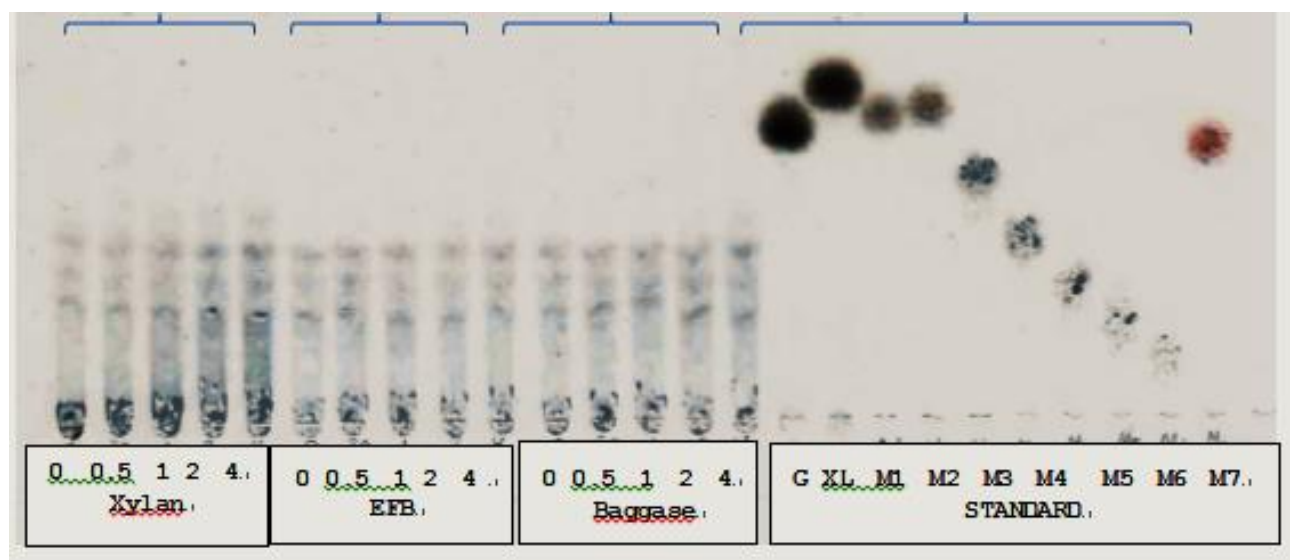

Figure 6. Thin layer chromatography analysis of hydrolysis products of xylanase X4 using xylan, EFB, Bagasse as a substrates. Standards (STD): glucose (G), xylose (M2), mannotriose (M3), mannotetraose (M4), mannopentaose (M5) and mannohexaose (M6). Substrate: enzyme $(\mathrm{v} / \mathrm{v})=1: 10$ and 1: 5, Substrate concentration $0.5 \%$ in $50 \mathrm{mM}$ sodium phosphate buffer (pH 6.0), reaction time (hours): $0,0.50,1,2,3$ and 4 at $30^{\circ} \mathrm{C}$ 


\section{Discussion}

The screening method uses congo red staining application by adding various substrates, i.e., CMC for cellulose, locust bean galactomannan substrate medium for mannanase, and xylan for xylanase, into ASW medium abilities to excrete enzyme in substrates are shown. The clear zone area that appears at the medium surface shows the positive activity of converting substrate (polymer) into specific derivate sugar by an enzyme from potential isolate for each substrate. The oligosaccharide production from locust bean gum as mannan source results in mannose, mannobiose, mannotriose, and mannotetraose. It means that mannanase from Bacillus subtilis has two enzyme types, exoenzyme, and endoenzyme, for polymer hydrolysis. Hydrolysis of xylan sources such as xylan birchwood, EFB, and baggase by Bacillus tequilensis results in xylotetraose, xylopetaose, and xylohexaose as the main product of the hydrolysis process, and it means Bacillus tequilensis bacteria belongs to exoenzyme type. Cellulase production from Bacillus cereus shows weak activity in raw biomasses.

In conclusion, the isolation of xylanolytic, mannolytic, and cellulolytic marine bacteria has been conducted from 20 isolates. It has been able to identify three potential isolates based on $16 \mathrm{~S}$ rDNA, and this process resulted in M8 (Bacillus subtilis), X4 (Bacillus tequilensis), and C9 (Bacillus cereus). Based on the TLC analysis, Mannanase M8 and Xylanase $\mathrm{X} 4$ had the potential to produce oligosaccharides with the size around tri-hexasaccharide as the main product.

\section{ACKNOWLEDGEMENTS}

This research was supported by DIPA Tematik Research Center for Biotechnology, Indonesian Institut of Sciences (LIPI), Cibinong, Bogor, Indonesia, FY 2014.

\section{REFERENCES}

Burggraf S, Olsen GJ, Stetter KO, Woese CR. 1992. A phylogenetic analysis of Aquifex pyrophilus. Syst Appl Microbial 15: 352-356.
Collins T, Meuwis MA, Stals I, Claeyssens M, Feller G, Gerday C. 2002. A novel family 8 xylanase: Functional and physicochemical characterization. J Biol Chem 277: 35133-35139.

Djohan AC. 2014. Isolasi dan Identifikasi Bakteri Manolitik Laut dari Pulau Pari [Thesis]. Institut Pertanian Bogor, Bogor. [Indonesian]

Ethier N, Talbot G, Sygusch J. 1998. Gene Cloning, DNA Sequencing, and Expression of Thermostable b-Mannanase from Bacillus stearothermophilus. Appl Environ Microbiol 64 (11): 4428-4432.

Guo B, Chen XL, Sun CY, Zhou BC, Zhang YZ. 2009. Gene cloning, expression, and characterization of a new cold-active and salt-tolerant endo- $\beta-1,4$-xylanase from marine Glaciecola mesophila KMM241. Appl Microbiol Biotechnol 84: 1107-1115.

Guo B, Li PY, Yue YS, Zhao HL, Dong S, Song XY, Sun CY, Zhang WX, Chen XL, Zhang XY, Zhou BC, Zhang YZ. 2013. Gene Cloning, Expression and Characterization of a Novel Xylanase from the Marine Bacterium, Glaciecola mesophila KMM241. Marine Drugs 11 (4): 1173-1187.

Kim DY, Su-Jin H, Hyun JL, Han-Young C, Ji-Hoon K, Yi-Joon K, Dong-Ha S, Young HR, Kwang-Hee S, Ho-Yong P. 2011. Cloning and characterization of a modular GH5 $\beta-1,4$-mannanase with high specific activity from the fibrolytic bacterium Cellulosimicrobium sp. Strain HY-13. Bioresour Technol 102: 9185-9192.

Li Y, Peilong Yang, Kun Meng, Yaru Wang, Huiying Luo, Ningfeng Wu, Yunliu Fan and Bin Yao. 2008. Gene Cloning, Expression, and Characterization of a Novel $\beta$-Mannanasefrom Bacillus circulans CGMCC 1416. J Microbiol Biotechnol 18 (1): 160-166.

Liu Z, Zhao XQ, Bai FW. 2012. Production of xylanase by an alkalinetolerant marine-derived Streptomyces viridochromogenes strain and improvement by ribosome engineering. Appl Microbiol Biotechnol DOI: $10.1007 / \mathrm{s} 00253-012-4290-y$.

Lv J, Y Chen, HPei, Wenhan Yang, Zhimin Li, Bing Dong, Yunhe Cao. 2013. Cloning, Expression, and Characterization of $\beta$-mannanase from Bacillus subtilis MAFIC-S11 in Pichia pastoris. Appl Biochem Biotechnol 169: 2326-2340.

Lynd LR, Weimer PJ, Van Zyl WH, Pretorius IS. 2002. Microbial Cellulose utilization: Fundamentals and Biotechnology. Microbiol Mol Rev 66: 506-577.

Ma Y, Xue Y, Dou Y, Xu Z, Tao W, Zhou P. 2004. Characterization and gene cloning of a novel $b$-mannanase from alkaliphilic Bacillus sp. N16-5. Mol Biol Evol 4: 406-425.

Mandels M. Sternberg D. 1976. Recent advances in cellulase technology. Ferment Technol 54: 267-286

Miller GL. 1959. Use of dinitrosalicylic acid reagent for determination of reducing sugar. Anal Chem 31 (3): 426-428.

Wu S, Liu B, Zhang X. 2006. Characterization of a recombinant thermostable xylanase from deep-sea thermophilic Geobacillus sp. MT-1 in East Pacific. Appl Microbiol Biotechnol 72: 1210-1216.

Yang P, Li Y, Wang Y, Meng K, Luo H, Yuan TZ, Bai YG, Zhan YC, Yao B. 2009. A Novel $\beta$-mannanase with High Specific Activity from Bacillus circulans CGMCC1554: Gene cloning, expression, and enzymatic characterization. Appl Biochem Biotechnol 159: 85-94. 